\title{
INVESTIGATING THE FINANCIAL CLOSE OF PROJ ECTS WITHIN THE SOUTH AFRICAN RENEWABLE ENERGY INDEPENDENT POWER PRODUCER PROCUREMENT PROGRAMME
}

\author{
I.J. Pieters ${ }^{1}$, M. Lotz ${ }^{1,2} \&$ A.C. Brent ${ }^{3 *}$ \\ ${ }^{1}$ Graduate School of Technology Management \\ University of Pretoria, South Africa \\ lan.pieters@aurecongroup.com \\ ${ }^{2}$ Enterprise Governance and Compliance \\ Nedbank Ltd, South Africa \\ marcol@nedbank.co.za \\ ${ }^{3}$ Department of Industrial Engineering and \\ The Centre for Renewable and Sustainable Energy Studies (CRSES), \\ University of Stellenbosch, South Africa \\ acb@sun.ac.za
}

\begin{abstract}
South Africa may have a generation capacity shortage in the near future. The Renewable Energy Independent Power Producer Procurement Programme (REIPPPP) is playing an important role in creating generation capacity to fulfil future demand requirements. This investigation focused primarily on identifying the problems that have been experienced with projects in the programme (e.g., to reach financial close). The research showed that there is good alignment between the requirements in the request for proposals and those from financiers. Several issues caused delays in projects reaching financial close. However, respondents to this study indicated that the REIPPPP is well thought out and that several problems are being addressed successfully.
\end{abstract}

\section{OPSOMMING}

Suid-Afrika kan in die nabye toekoms ' $n$ tekort aan elektrisiteit opwekkingsvermoë ervaar. Die regering se onafhanklike kragopwekkers groenkrag-aankoopprogram - of te wel die REIPPPP - speel ' $n$ belangrike rol in die skep van opwekkingsvermoë om aan toekomstige aanvraag vereistes te voldoen. Hierdie navorsing het primêr gefokus op die identifisering van die probleme wat ondervind is deur projekte in die program - spesifiek met finansiële sluiting. Dié navorsing toon dat daar 'n goeie korrelasie tussen die vereistes van die regering - in die navrae na voorstelle - en dié van finansierders is. Verskeie probleme het vertragings in finansiële sluiting van projekte veroorsaak. Tog dui respondente van hierdie studie aan dat die program goed deurdag is en dat verskeie probleme suksesvol aangespreek word.

\footnotetext{
${ }^{1}$ The author was enrolled for an M Eng (Project Management) degree in the Graduate School of Technology Management, University of Pretoria

* Corresponding Author
} 


\section{$1 \quad$ INTRODUCTION}

In the last decade, a need has been identified for the development of additional electricity generation capacity in South Africa [1]. The need for this development originates from a shortage of generation capacity based on the projected electrical load growth over the next 15 to 20 years [2] and the low electricity reserve margin [1, 3]. To help address this problem, the Department of Energy (DoE), with the assistance of the National Treasury, has implemented the Renewable Energy Independent Power Producer Procurement Programme (REIPPPP). One of the aims of this programme is to accelerate the implementation of local renewable energy (RE) generation. In 2012, the first REIPPPP projects in the programme reached financial close. However, these projects have encountered many problems and delays in reaching financial close. Examining these projects can provide much learning, which could prove valuable in streamlining the execution of similar future projects.

Eskom, South Africa's main electricity utility, has increased electricity tariffs significantly in recent years in order to fund new generation capacity. The country has historically had relatively low prices for electricity [1]; however, these low prices did not make sufficient provision for the capital costs necessary to expand generation capacity [4]. Despite the recent increases in electricity tariffs, South Africa still has relatively low price electricity, which has, to some extent, restricted the creation of new generation capacity by Eskom or through independent power producers (IPPs) [3]. Eskom has estimated that current electricity tariffs are still almost 30 per cent below what is needed to cover its costs, including those for the required capacity expansion, as put forward in its Integrated Resource Plan (IRP) [2, 4].

Pegels [1] states that the South African electricity sector faces three main challenges:

1. An undersupply of electricity: South Africa has a narrow reserve power margin, and the IRP has projected that the electricity demand will double in the next 20 years.

2. Funding problems for Eskom: Eskom will need an estimated ZAR 300 billion to upgrade and expand electrical infrastructure, but they are underfunded.

3. High greenhouse gas (GHG) emissions due to the country's largely fossil fuel-based generation capacity. GHGs are a climate change driver, and can lead to environmental damage.

De Beer [5] adds to this, indicating that market constraints as a result of the absence of market reform - for example, the establishment of an independent system and market operator - is also a major restriction that is often overlooked.

\subsection{The South African stance on green growth}

South Africa accounted for 37 per cent of Africa's $\mathrm{CO}_{2}$ emissions from fuel combustion in 2010, due to the high percentage of electricity produced by coal-fired power stations [6, 7]. The country needs to focus on reducing its reliance on coal to reduce anthropogenic GHG emissions from the power sector. There is also pressure from the international community to move towards cleaner forms of energy. In 2009, during the 15th Conference of the Parties (COP 15) meeting, South Africa committed to limit the growth of GHG emissions to 34 per cent by 2020 and 42 per cent by 2025, relative to business as usual (BAU) [7]. Investment in the development of RE generation capacity is thus needed. Although RE plays a limited role in mitigating climate change, other aspects support its implementation. Aspects particularly relevant to South Africa are [8]:

- $\quad$ RE contributes to the reduction of other pollutants and related risks arising from conventional energy sources.

- RE contributes to increased energy security and reduces fossil fuel dependence.

- $\quad$ RE hedges against the volatility and long-term increases of fossil fuel prices.

- RE contributes to developing local employment. 


\subsection{Historical renewable energy (RE) barriers in South Africa}

In the South African context, factors that may inhibit the development of RE projects can be summarised as:

- The lack of a formal and coherent approach to energy technology assessment from a sustainability perspective [9].

- The country's abundant coal reserves, and a historical bias towards using coal generation [1].

- Until recently, confusing and out-dated legislation and policy around these projects $[3,10]$.

- The difficult of obtaining funds due to the perceived high risks of these projects [1].

To promote RE development, the National Energy Regulator of South Africa (NERSA) initially looked at using a Renewable Energy Feed-in Tariff (REFIT). This would allow IPPs to cover costs and receive a reasonable return on investment. In 2011, however, the REFIT programme was abandoned [11] and replaced with the Renewable Energy Bidding (REBID) programme, or REIPPPP.

The REIPPPP was officially launched in August 2011. It requires prospective IPPs to submit a bid with a proposed tariff for Eskom (the buyer). The bid also has to include details on the proposed delivery of social and economic development for South Africans through their projects. Only after social and economic development plans are found to be sufficient will projects be adjudged on feasibility and tariff [11].

The bidding qualification and evaluation criteria are set out in the request for qualification and proposals for new generation capacity, also known as the REIPPPP Request for Proposals (RFP) [12]. Bids are assessed on the basis of compliance in two criteria categories: qualification criteria, and evaluation criteria. The programme is being executed in 'bid windows' and has set milestones for potential bidders [13]. However, these milestones have been moved regularly.

\subsection{Objectives of this paper}

The third round of bidding in the REIPPPP is complete, and the first and second round projects have reached financial close. Government is also now planning to convert the REIPPPP into a rolling programme [14]. This, in conjunction with the problems that have thus far been encountered by developers, warrants further investigation. It is thus the ideal time to examine the projects involved in the REIPPPP that have been successfully brought to financial close.

The associated research questions that this paper aims to address, within the context of the REIPPPP, are the following:

- How good is the alignment between REIPPPP project selection requirements and the requirements of financiers?

- What is required from financiers, before funding for a project within the REIPPPP is approved?

- Why were REIPPPP projects delayed in reaching financial close?

\section{PROJ ECT FINANCE}

Project finance is based on the principle that lenders provide a loan for the development of a project, taking into consideration the project's risks and the cash flow projections. Lenders have no recourse, or only limited recourse, to the developer of a project should the project fail [15]. This is important for project development in emerging markets, where lenders often have to rely on guarantees, long-term off-take agreements, and other contractual agreements as security $[15,16]$. 
The most important factors that lenders consider in assessing the financability of an IPP project are the power purchase agreement (PPA), engineering procurement and construction (EPC) agreement, operations and maintenance (O\&M) agreement, technology risks, and market risks [16]. Lenders also prefer a full EPC contract with a single point of responsibility ${ }^{2}$ and a risk allocation between the developer and the contractor that satisfies the lender [15, 17]. According to Yescombe [16], financial close is reached when all project contracts, financing documentation, and agreements have been signed, and all conditions from the lenders have been fulfilled or waived. In general, lenders for REIPPPP projects require the following [18]:

- A fixed project completion date;

- A fixed project cost;

- $\quad$ Limited technology risk;

- Guarantees of the project output;

- $\quad$ Liquidated damages for delays and project performance;

- $\quad$ Some form of security from the contractor; and

- Restrictions on contractors' ability to claim extensions of time and additional costs.

Considering all the required documentation, the period between signing the loan documentation and reaching financial close can be lengthy, and developers need to ensure that the process is managed effectively to avoid delays [16].

\section{RESEARCH METHODOLOGY}

A case study emerged as the preferred strategy. Unfortunately, case studies have traditionally been viewed as lacking reliability and validity when compared with other research methods. Flyvbjerg [19], however, indicates that these are common misconceptions, and argues the following (emphasis added):

- $\quad$ Context-dependent knowledge is more valuable than theoretical knowledge.

- Formal generalisation is overvalued in research, while the individual example is underestimated.

- The case study has no greater bias toward verification of the researcher's preconceived notions than other methods of inquiry.

- The case study is useful for both generating and testing of hypotheses.

- Good case studies should be read as narratives in their entirety, in order to understand the context of the case.

These arguments support the notion that case studies can contribute valuable, valid, and reliable information to any field of study. To enhance the quality of the research further, tactics to address the four research quality tests [20] were considered in the research design:

1. Construct validity: multiple sources of evidence were used to achieve data triangulation.

2. Internal validity: pattern-matching was performed on the data collected.

3. External validity: the domain in which the study's findings can be generalised is clearly defined.

4. Reliability: a case study protocol was used and a chain of evidence was maintained.

Yin [20] states that multiple cases provide analytic benefits and more powerful conclusions than a single case. With this argument in mind, it was decided that case studies would be performed on several REIPPPP projects that have reached financial close. To increase the

\footnotetext{
${ }^{2}$ Although in some renewable energy projects the EPC contract is sometimes split into an Equipment EPC contract (e.g., wind turbines) and a Balance of Plant EPC contract (e.g., civil and electrical works) [16]. 
external validity of the research further, an embedded case study design was used. For this purpose, the projects were analysed from various points of view.

To address the research questions and to assess the key requirements that play a role in bringing REIPPPP projects to financial close, a framework of themes that have been identified was created. The framework for organising a case study serves as a good analytic strategy [21]. From the literature that was studied, it was deduced that bid selection criteria, project financing structures, and requirements to reach financial close would be important areas to investigate. The problems encountered in the REIPPPP were identified as another important area to investigate. The following themes then formed the basis for this case study:

- $\quad$ Lenders' bankability criteria versus RFP qualification and evaluation criteria.

- $\quad$ Structuring of financing for RE projects.

- Requirements for reaching financial close.

- $\quad$ Problems and delays encountered in the REIPPPP.

By analysing each of these gaps, redundancies and circular conditions between the lenders' bankability criteria and the RFP qualification and evaluation criteria could be identified to generate answers for the research questions.

\subsection{Embedded research methodologies}

The embedded case study design readily lends itself to mixed methods research. Using mixed methods can allow researchers to address more complicated research questions and collect richer evidence than a single method [20].

For this particular case study approach, semi-structured interviews were used. The unit of analysis for the semi-structured interviews was the projects within the REIPPPP. The projects were analysed from various points of view to increase further the external validity of the research. These included:

- $\quad$ Project developers who are participating in the REIPPPP;

- Commercial banks and development finance institutions (DFIs) that are providing debt to REIPPPP projects; and

- Local experts and consultants on RE in South Africa.

\subsection{Case study selection}

This study selected the projects that were chosen as preferred bidders in the first two rounds of bidding in the REIPPPP. Although this selection ensured that the events were current, it also meant that there was a scarcity of academic literature specific to the programme. Many of the developers and lenders who were identified to participate in the study were unavailable for interviews, due to their participation in the third round of bidding. Another issue that presented itself was the confidential nature of the information that was requested from participants. Several parties who were approached declined to participate because of this. It was agreed with interviewees that no confidential information would be shared in the research, and that no specific views and comments would be attributed to any individual or company.

Thus no information in this article can be attributed to a specific project due to the confidential nature of the subject matter. Some indication of typical projects that were studied should be given for the research to deliver valid results, which can be interpreted within the correct boundaries. Typical projects that were studied are then as follows:

- Typical large onshore wind farms (70 MW to $150 \mathrm{MW}$ ): an example of such a plant is the Tsitsikamma Community Wind Farm, a 95 MW plant situated in the Eastern Cape Province that comprises 31 wind turbine generators. 
- Typical small onshore wind farms (10 MW to $70 \mathrm{MW}$ ): an example of such a plant is the Dassiesklip Wind Energy Facility, a 27MW plant situated in the Western Cape Province that comprises nine wind turbine generators and uses an area of 350 hectares.

- Typical small solar photovoltaic (PV) plants (5 MW to $30 \mathrm{MW}$ ): an example of such a plant is the Greefspan PV Power Plant, an 11MW plant situated in the Northern Cape Province that comprises approximately 45000 solar PV panels and uses an area of 44 hectares.

Figure 1 is a graphic representation of the case study design that was used. The figure indicates the context in which each selected embedded unit of analysis was studied.

Research space: Renewable Energy Independent Power Producer Procurement Programme

\begin{tabular}{|c|c|c|}
\hline \multicolumn{2}{|c|}{$\begin{array}{l}\text { Case Study } 1 \text { : } \\
\text { Onshore wind generation }\end{array}$} & $\begin{array}{l}\text { Case Study 2: } \\
\text { Solar PV generation }\end{array}$ \\
\hline Unit of analysis 1.1 & Unit of analysis 1.2 & Unit of analysis 2.1 \\
\hline $\begin{array}{l}\text { Typical large onshore } \\
\text { wind farms ( } 70 \mathrm{MW} \text { - } \\
150 \mathrm{MW} \text { ), for } \\
\text { example: } \\
\text { - Cookhouse Wind } \\
\text { Farm - } 135 \mathrm{MW} \\
\text { - Tsitsikamma } \\
\text { Community Wind } \\
\text { Farm - 95 MW }\end{array}$ & $\begin{array}{l}\text { Typical small onshore } \\
\text { wind farms ( } 1 \mathrm{MW}-70 \\
\text { MW), for example: } \\
\text { - Dassiesklip Wind } \\
\text { Energy Facility - } \\
27 \mathrm{MW}\end{array}$ & $\begin{array}{l}\text { Typical small solar PV } \\
\text { plants ( } 5 \mathrm{MW}-30 \mathrm{MW}) \text {, } \\
\text { for example: } \\
\text { - Greefspan PV } \\
\quad \text { Power Plant - } 11 \\
\text { MW } \\
\text { Aries Solar Energy } \\
\text { Facility - } 10 \mathrm{MW}\end{array}$ \\
\hline
\end{tabular}

Figure 1: Research case study design

\section{RESULTS: DATA GATHERED AND ANALYSIS}

\subsection{Lenders' bankability criteria versus RFP qualification and evaluation criteria}

The respondents all agreed that the REIPPPP and RFP were well-developed and formulated through wide consultation with various stakeholders. In general, the majority of the respondents agreed that there is a high degree of alignment between the criteria set out in the RFP and the bankability criteria of lenders. The conservative approach of the DoE in the RFP is aligned with the approach of lenders. The RFP created a good framework wherein the developers had to structure the project and formed a base from which lenders could assess projects. The lenders' criteria, however, elaborate on the RFP criteria and are much more onerous and extensive. Overall, it can be deduced that while the RFP looks for an indication of the 'degree of readiness' of each project, which includes financing arrangements, contracts, regulatory issues, and feasibility work, the lenders focus much more on the degree of risk associated with each project.

\subsubsection{Legal criteria, land acquisition, and use permitting}

Lenders were of the opinion that the amount of legal and regulatory documentation required for a bid submission was reasonable, although they were aware that the documentation that is required is extensive and time-consuming. This perception can be attributed to the reduction of risk in the projects when legal requirements are fulfilled. On the other hand, developers were of the opinion that the extent of legal and regulatory requirements was too burdensome for a bid submission. They did, however, understand the necessity for the comprehensive requirements, as they ensure that a preferred bidder will have a project that is ready to be executed. This perception can also be attributed to the amount of risk and development costs associated with fulfilling these requirements. This correlates well with a study of the regulatory processes in the REIPPPP [22], which states: 
"A number of developers felt that the RFP was too detailed and required developers to be too advanced in securing all the eventual regulatory requirements for the projects. However, they acknowledged that they understood why this was done and did accept that it reduced the risks of projects failing after being selected."

First-time participants experienced some problems with identifying the necessary permits and authorisations that needed to be obtained. The RFP listed some requirements, but it was not clear exactly what was needed in addition. The identification of all other regulatory requirements was left to the developers.

\subsubsection{Technical criteria}

Developers experienced the technical requirements in the RFP and from the lenders as reasonable. Lenders wanted much more detail, which developers expected. Detailed technical data decreased the perceived risk of a project. Lenders particularly focused on the production estimates, equipment, and EPC conditions. Lenders were looking for minimal risk on the projects, while the RFP was looking for a viable project.

There were some concerns about the geographic distribution of the IPPs. Grid capacity limitations could affect the feasibility of projects due to the concentration of plants in certain areas. This concern might, however, gradually disappear as obvious RE locations are taken up and developers are forced to look at more difficult areas.

\subsubsection{Economic development criteria}

Several issues were mentioned when it came to the economic development criteria. Although the criteria are easily measurable, there were some concerns about the specifications on local content and local community shareholding.

The need for certain percentages of South African ownership, black ownership, and local content decreased the bankability of projects to some extent. This was because the requirements were difficult to comply with and created extra risk (or perceived risk) for the projects. Some developers felt that these criteria would not achieve the desired objectives.

The local content requirements generally increased the EPC costs, and may have a more significant impact on the EPC costs as they increase. This is in conflict with the aim to decrease the cost of RE. The lack of manufacturing capacity in the country, along with the lack of clear specifications about how far down the supply chain content would need to be local, also created some problems. For instance, is it sufficient that wind turbine towers are manufactured locally from imported steel?

It was also pointed out by some respondents that if government wants to achieve the economic development goals of the REIPPPP, the weighting of these criteria would have to be much higher in bid selection. It was felt that developers who attempted to achieve the economic development requirements did not receive enough benefit from this. This was because price was too heavily weighted in the selection criteria. ${ }^{3}$

\subsubsection{Environmental consent criteria}

In general, the environmental criteria were perceived as reasonable and well-managed. The process did not allow developers to take any shortcuts. This correlates with PDG's [22] findings that many developers did not raise maj or problems with the Environmental Impact Assessment (EIA) process. In general, the national Department of Environment Affairs (DEA) dealt with most projects, and their authorisation processes were generally in line with the legislated time frames.

The EIA process generally lasted about 14 months, which is in line with the National Environmental Management Act's (NEMA) requirements for a full EIA, which stipulates that it should last 12 months. For wind farms specifically, 12 months had to be allocated to bird

3 Price had a weighting of 70 per cent and economic development 30 per cent in the RFP [12]. 
and bat monitoring. Detailed information was required before site layouts would be approved. Some wind farms had to amend the micro-siting to accommodate bird and bat migratory paths, for example.

In addition to the RFP requirements, some developers had to confirm that they comply with the Equator Principles (EP) [23]. Three of South Africa's major banks are members of the EP Association. Members only provide project finance to projects that meet the requirements of the ten EP. The ElA needs some adjustment before being accepted by lenders if it does not align with the EP.

\subsubsection{Financial and price criteria}

The project cost and tariff were probably the most important aspect for all parties involved. The DoE (through the RFP price caps) is attempting gradually to decrease the tariffs as competition in the industry increases. Project developers are attempting to maximise their returns while keeping the proposed tariffs at a competitive level. Lenders are looking for a realistic tariff that will expose the projects to the least amount of risk.

Complications were experienced due to the tariff that had to be finalised for the bid submission. The period from preferred bidder selection to financial close generally lasted six months to a year. Unfortunately, for the first two rounds during this period, the global economy worsened, which meant that EPC prices increased significantly.

Problems also occurred when finalising EPC contracts from the heads of terms (HoT) provided for bid submission. Respondents highlighted this as one of the major causes of delays in reaching financial close. This problem was compounded by the RFP preventing changes in EPC contractors after bid submission. EPC prices increased due to the delays and restrictions, and had a major impact on the achievable internal rate of return (IRR) for projects. This caused some projects to become financially marginal.

\subsection{Structuring of financing for renewable energy projects}

The lenders primarily controlled the structuring of financing for the projects. They generally followed international best practices for financing RE projects, although the approach, especially for the first round, might have been much more conservative. Typical financial parameters, as provided by the respondents, are shown in Table 1.

Table 1: Typical financial parameters for REIPPPP projects

\begin{tabular}{|l|l|}
\hline \multicolumn{1}{|c|}{ Parameter } & \multicolumn{1}{|c|}{ Typical range } \\
\hline Debt/ equity ratio & $70 / 30-80 / 20$ \\
\hline Loan term & $15-17$ years \\
\hline \multirow{3}{*}{ Debt service coverage ratio (DSCR) } & $4.35-1.25$ annual DSCR \\
& $1.15-1.2$ dividend lock-up DSCR \\
& $1.05-1.1$ project default DSCR \\
\hline Type of lender & Single commercial lender \\
\hline IRR & $15-20 \%$ \\
\hline Weighted average cost of capital & $10-12 \%$ (J ohannesburg interbank agreed rate [J IBAR] used \\
(WACC) & as base) \\
\hline
\end{tabular}

The debt/equity ratio and debt service coverage ratio (DSCR) ${ }^{4}$ required on a project improved as the appetite of lenders to participate in the REIPPPP increased. The first round projects were mainly financed at a debt/ equity ratio of $70 / 30$. As the perceived risk of these projects declined and market competitiveness increased, debt was increased to

\footnotetext{
${ }^{4}$ Annual DSCR is the ratio between the annual available cash to service the annual debt and the annual debt. Dividend lock-up DSCR is the DSCR below which dividend distributions are prevented. Project Default DSCR is the DSCR below which the lender can take over control of the project or require all debt to be repaid.
} 
$80 / 20$. In some instances, 5 per cent mezzanine ${ }^{5}$ loans were provided (debt/ equity ratio of $75 / 5 / 20$ ) to increase the attractiveness of a project and allow the developers to bid a lower tariff; loan terms also increased. First round projects were financed with a loan term of 15 years, while later projects received terms of up to 17 years. The annual DSCR could go as low as 1.25 for some projects, while the projects' default DSCR could go as low as 1.05 .

During the discussions, it became clear that a single lender was preferred over multiple lenders (and syndicated loans). Multiple lenders were, however, necessitated sometimes by the size and risk of a project. DFI funding appeared to be rare in the projects evaluated. Many developers felt that DFI interest rates were high, and that the requirements to obtain DFI funding were too burdensome.

Development costs for the projects, usually around ZAR 10-20 million, had to be carried by the developers. This high cost was mainly ascribed to the amount of detail needed by bid submission. These high development costs presented high risk to developers, especially due to the possible losses that would have to be endured if a bid were not selected. These high risks and costs meant that new, smaller, or less sophisticated development companies could not easily compete with well-funded and experienced bidders.

\subsection{Requirements for reaching financial close}

The requirements for reaching financial close on the REIPPPP projects seem quite clear. They are no different from any other project-financed project. However, the process of achieving these requirements is extremely challenging. Identifying and obtaining all the necessary documentation in a reasonable time proved to be difficult for most respondents, especially for first-time participants.

Apart from all the RFP and regulatory requirements, lenders and equity investors were concerned mostly about the long-term viability and credibility of any original equipment manufacturer (OEM) or EPC contractor on the projects. A result of this was that lenders required strict EPC and equipment guarantees. One respondent pointed out that these guarantees were more expensive than international norms. Some of the guarantees that were required included:

- A parent company guarantee from equity providers;

- $\quad$ Performance guarantees and parent company guarantees from the EPC contractor; and

- EPC payment guarantees from equity and debt providers.

Lenders also required a wrapped EPC contract with one party responsible for delivering guarantees. This could mainly be ascribed to the degree of risk that the lenders were willing to be exposed to. OEMs generally do not prefer this arrangement, as they would ideally want only to supply equipment without getting too deeply involved in the projects.

According to DLA Cliffe Dekker Hofmeyer [17], the following is included in the requirements to reach financial close:

- $\quad$ Power Purchase Agreement (PPA) with Eskom;

- Implementation Agreement (IA) with the DoE;

- Transmission Agreement or Distribution Agreement (as relevant);

- $\quad$ Direct Agreement; and

- $\quad$ Fully termed EPC and O\&M contract.

Not including the problems with the EPC contract finalisation, respondents generally did not experience any issues with the above-mentioned agreements.

\footnotetext{
${ }^{5}$ The use of a mezzanine facility increases the DSCR to a more acceptable level, as the DSCR is only calculated using the senior debt. Mezzanine facilities are more expensive than senior debt, but cheaper than equity.
} 


\subsection{Problems and delays encountered in the REIPPPP}

Several problems and delays were experienced in bringing the REIPPPP projects to financial close. In spite of the well-thought-out and highly successful programme, some issues are still being addressed. The evaluation of the comprehensive bid documentation put strain on the DoE and created delays in the programme. Some developers mentioned that the limited number of local and suitably-qualified resources, especially law firms and banks, were sometimes overloaded. This was due to the amount of work that had to be completed on multiple projects, in a short time, to accomplish the target dates.

Eskom grid connection issues were a major cause of delays. Eskom timelines (up to 24 months) impacted EPC prices and construction interest. This reduced the incentive to complete projects earlier than the schedules. The costing provided by Eskom was also problematic. Bidders usually had to submit a bid with a grid connection cost estimation from Eskom, which was around 60 per cent accurate. A price from Eskom that was 80 per cent accurate would usually cost around ZAR 2-2.5 million. This created a major risk for developers who had to finalise the tariff on a 60 per cent accurate grid connection price.

The water use licence application frustrated many developers. This could only be obtained from the Department of Water Affairs (DWA) after selection as a preferred bidder. Detailed designs had to be submitted for each water crossing in the plant, and these designs were done at great cost and risk for the developers.

The level of detail required in a bid created the problem of high development costs, which needed to be carried at risk. The respondents indicated that too much detail on certain aspects of the projects was required at the bidding stage. This caused four problems:

1. Bidders were struggling to get complete information for bid submission.

2. Delays in bidding dates caused many developers to run out of funding, and led other interested parties to look elsewhere for better opportunities.

3. New and smaller development companies could not easily compete with well-funded and experienced bidders.

4. The amount of documentation that had to be reviewed in the preferred bidder selection process put huge pressure on the selection timelines and resources.

Lastly, some respondents identified the risk of selling the power that is produced to Eskom alone as a major issue. The risk lies in that if the PPA of any producer is retracted for any reason, they will not be able to sell the power elsewhere. This problem increases the risk in all projects, and consequently has an impact on interest rates provided by lenders.

\section{CONCLUSION}

The REIPPPP bidding is becoming increasingly competitive. This is, to a certain degree, nullifying the need for tariff price caps in the RFP. Lenders are also gaining confidence in the programme, and seem to have a growing appetite for participation in REIPPPP projects. During the latest bidding round, lenders were offering more competitive financing structures, and developers accepted lower returns, resulting in more competitive bidding for these projects and lower RE tariffs. Many respondents were of the opinion that the RE tariffs have reached optimum levels and are unlikely to continue decreasing. The DoE has at least reached one goal in achieving low and competitive RE electricity prices.

This study attempted to answer the following research questions:

- How good is the alignment between REIPPPP project selection requirements and the requirements of financiers?

- What is required from financiers before funding for a project within the REIPPPP is approved?

- Why were REIPPPP projects delayed in reaching financial close? 


\subsection{Alignment of REIPPPP selection requirements and the requirements of financiers}

The respondents indicated that there is good alignment between the requirements in the RFP and the requirements from financiers. The RFP was formulated through wide consultation with industry players and international advisors, and is evolving with each round. The entire process was widely complimented by respondents, which shows that it is gaining the confidence of developers and lenders. There are, however, some issues that can be addressed, and some streamlining of the process is needed.

The detailed requirements at bid submission fit well with the risk averseness of lenders and ensure that sound projects are selected. Conversely, the level of investment that is needed pre-bid poses a problem for some developers. Developers feel that they are exposed to huge risk and financial loss if they are not selected as a preferred bidder.

\subsection{Requirements of financiers for funding a project within the REIPPPP}

Apart from the agreements, permits, and authorisations required, lenders were mostly concerned about their exposure to risk on projects. This meant that detailed due diligence work was completed on each aspect of a project by independent lender advisors. Most of the information required at bid submission was more stringently verified and assessed by lenders. Lenders also required strict EPC and equipment guarantees, including parent company and performance guarantees. In finalising these contracts, lenders attempted to limit their exposure to risk as far as possible. As lenders gained more confidence in the process, stringent lender requirements were relaxed to some extent, especially with regard to debt/ equity ratios and loan terms. This allowed projects to be structured more competitively with regard to financing.

\subsection{Delays in reaching financial close for REIPPPP projects}

The entire process was governed by milestone dates that were set by the DoE. These dates were extended on several occasions, but several other issues also caused delays in the financial close timeline for projects. The finalisation of EPC contracts, grid connection timelines provided by Eskom (up to 24 months), and the water use licence application process were some of the main causes of delays, especially for first-time participants in the programme. Experienced developers who were aware of what was needed could, however, manage the process to avoid these problems.

\section{RECOMMENDATIONS FOR FURTHER RESEARCH}

Several opportunities for further research have arisen from this study. Such research is especially important to streamline and improve the REIPPPP process further:

- $\quad$ Tariff finalisation timing: Research regarding the timing of fixing the proposed tariff is required. At present this happens at bid submission, but the developers are then exposed to EPC price variations, grid connection price variations, and exchange rate fluctuations. A possible solution is to use a stage-gate selection process. During the first stage of selection, bids will be evaluated on feasibility merit. During the second selection stage, projects will be evaluated on price and economic development criteria.

- Economic development criteria weighting: Uncertainty exists surrounding the weighting of economic development criteria, specifically local content requirements, against price. Presently, price has a weighting of 70 per cent versus the 30 per cent for economic development. Research is needed to ascertain what would add more value to the South African economy: increasing local manufacturing capabilities or decreasing the price of electricity?

- Grid location of generation plants: The issue of geographical generation distribution can become a major one if not addressed. Geographically, South Africa already has very centralised generation. This has a significant impact on the reliability and stability of the national grid. Research is needed to establish which geographical areas in South Africa would benefit from local generation. 
- $\quad$ PPA terms: Two possible areas for research regarding PPAs in the REIPPPP have been identified. There is a research opportunity in determining what the optimum duration of a PPA would be. Currently, the PPAs are only valid for 20 years after COD, but the plant life of a project can be significantly longer. Another research opportunity lies in determining the implications of selling electricity into the Southern African power pool (SAPP) instead of only to Eskom. This would present many opportunities to developers, but could also create some problems with wheeling electricity through the Eskom grid.

\section{REFERENCES}

[1] Pegels, A. 2010. Renewable energy in South Africa: Potentials, barriers and options for support. Energy Policy, 38(9), pp. 4945-4954.

[2] Department of Energy. 2011. Integrated resource plan for electricity 2010-2030, Revision 2. Republic of South Africa: Department of Energy..

[3] Baker, L. 2011. Governing electricity in South Africa: Wind, coal and power struggles. The Governance of Clean Development Working Paper Series, Working Paper 15.

[4] OECD. 2013. OECD Economic Surveys: South Africa 2013. OECD Publishing.

[5] De Beer, W. 2013. Discussion about the current South African electricity market condition. Interviewed on 26 September 2013.

[6] International Energy Agency. 2012. $\mathrm{CO}_{2}$ emissions from fuel combustion highlights. IEA Publications.

[7] Tyler, E. 2010. Aligning South African energy and climate change mitigation policy. Climate Policy, 10(5), pp. 575-588.

[8] Philibert, C. 2011. Renewable energy policy and climate policy interactions. International Energy Agency Climate \& Electricity Annual 2011 - Data and analyses, pp. 35-42.

[9] Musango, J.K. \& Brent, A.C. 2011. Assessing the sustainability of energy technological systems in Southern Africa: A review and way forward. Technology in Society, 33(1-2), pp. 145-155.

[10] Sebitosi, A. \& Pillay, P. 2008. Renewable energy and the environment in South Africa: A way forward. Energy Policy, 36(9), pp. 3312-3316.

[11] Fritz, W. 2012. Renewable energy feed in tariffs, REBID, SASGI and the smart grid. Energize, October, pp. 77-80.

[12] Department of Energy. 2011. Tender No: DOE/001/2011/2012: Request for qualification and proposals for new generation capacity under the IPP Procurement Programme. Republic of South Africa: Department of Energy..

[13] DoE, Eskom, NERSA. 2012. IPP Procurement Programme. Retrieved from www. ipprenewables.co.za. Accessed on 23 J anuary 2013.

[14] Research Channel Africa. 2013. A review of South Africa's electricity sector, January 2013. Creamer Media.

[15] Groobey, C., Pierce, J., Faber, M. \& Broome, G. 2010. Project finance primer for renewable energy and clean tech projects. Wilson Sonsini Goodrich \& Rosati Professional Corporation.

[16] Yescombe, E.R. 2002. Principles of project finance. $1^{\text {st }}$ edition, Academic Press.

[17] DLA Cliffe Dekker Hofmeyr. 2012. Finance \& projects update: EPC contracts for wind energy projects - South African RE IPP Programme - lessons learned from phases 1 and 2. DLA Piper.

[18] DLA Cliffe Dekker Hofmeyr. 2011. EPC contracts in the power sector. DLA Piper.

[19] Flyvbjerg, B. 2006. Five misunderstandings about case-study research. Qualitative Inquiry, 12(2), pp. 219-245.

[20] Yin, R.K. 2013. Case study research: Design and methods. $5^{\text {th }}$ edition, SAGE Publications.

[21] Rowley, J. 2002. Using case studies in research. Management Research News, 25(1), pp. 16-27.

[22] PDG. 2012. Mapping of authorization processes for renewable energy projects. PDG.

[23] The Equator Principles Association. 2013. The equator principles. The Equator Principles Association. 